\title{
Death Mechanisms in Airborne Escherichia coli
}

\author{
BY J. E. BENBOUGH \\ Microbiological Research Establishment, Porton Down, \\ near Salisbury, Wiltshire
}

(Accepted for publication 23 December 1966)

\begin{abstract}
SUMMARY
Differences in survival of Escherichia coli (strain B) sprayed from distilled water into air and into nitrogen as a function of relative humidity $(\mathrm{RH})$ are reported. Two mechanisms which may contribute to death of airborne bacteria are described. In air one death mechanism occurring at low $\mathrm{RH}$ is attributed to the action of oxygen causing damage to flavin-linked enzymes as a result of free radical activity. Free radical suppressors are therefore expected to protect airborne $E$. coli B. Also, electron transport inhibitors like sodium azide, 2,4-dinitrophenol and potassium cyanide are shown to protect $E$. coli в against lethal effects of oxygen. An analogy is drawn with effects of oxygen on freeze-dried $E$. coli B. A second death mechanism of $E$. coli B in air occurs at higher RH's and is considered to result from the effect of aerosolization on RNA synthesis. The activation of RNAse as a possible protection to bacteria in the post-aerosolization medium is discussed.
\end{abstract}

\section{INTRODUCTION}

Because the effect of aerosolization upon bacteria survival is related in a complex manner to relative humidity $(\mathrm{RH})$ of the atmosphere, earlier reports (Dunklin \& Puck, 1948; Davis \& Bateman, 1960; Bateman, McCaffrey, O’Connor \& Monk, 1961) have suggested that bacterial sensitivity increases at certain critical degrees of dehydration. Later reports (Hess, 1965; Cox, 1966) have shown that other factors, e.g. spray fluid, oxygen content of the carrier gas and the collecting fluid, influence the disruption of vital structures and the unbalancing of metabolism. Kinetic studies indicate that: (i) the loss of viability of bacteria is not a simple process; (ii) first-order reactions do not apply; (iii) typically, death rate is initially high and subsequently diminishes progressively.

The possibility that overlapping lethal mechanisms exist, makes it extremely difficult to identify bacterial death by a given mechanism in a given set of conditions. One approach to the problem is the use of inert atmospheres to limit the effect of gaseous factors. Another is comparison between results of analogous studies, such as freeze-drying experiments, to derive support for evidence produced in aerosol tests. This paper reports results of such investigations.

\section{METHODS}

Growth of organisms

Cultures of Escherichia coli (strain B) were grown in $100 \mathrm{ml}$. of a chemically defined medium for $16 \mathrm{hr}$ at $37^{\circ}$, using a shake flask technique. The medium consists of 
$1.0 \%$ (w/v) glycerol; $0.5 \%$ ammonium citrate; $1.0 \% \mathrm{~K}_{2} \mathrm{HPO}_{4} .3 \mathrm{H}_{2} \mathrm{O} ; 0.05 \% \mathrm{MgSO}_{4}$. $7 \mathrm{H}_{2} \mathrm{O} ; 0.05 \% \mathrm{NaCl} ; 0.005 \%$ ferric ammonium citrate; the $\mathrm{pH}$ being adjusted to 7.0 , using dilute caustic soda solution.

\section{Preparation of spray suspensions, survival estimation, apparatus and collecting fuids}

The procedure was the same as described by Cox (1966) except that aerosols were generated by a 3-jet Collison spray and stored in a 5001 . rotating stainless steel drum. Aerosol samples were collected into phosphate buffer.

\section{Technique for obtaining higher numbers of bacteria recovered from the aerosol}

In order to detect measurable differences in their metabolism an adequate quantity of airborne bacteria must be recovered. Consequently the following modifications in spraying and collecting techniques were adopted: (i) the bacterial population of the spray fluid was increased tenfold to $10^{11}$ organisms $/ \mathrm{ml}$.; (ii) the 3-jet Collison spray was replaced by an 18-jet Collison spray; (iii) bacteria were sprayed into the drum for $2 \mathrm{~min}$. instead of $1 \mathrm{~min}$.; (iv) collection of the aerosolized bacteria was by a $551 . / \mathrm{min}$. subsonic impinger (K. R. May, personal communication) for $5 \mathrm{~min}$. The bacterial population collected was measured turbidimetrically by an EEL spectrophotometer.

\section{$\left({ }^{14} \mathrm{C}\right)$-Uracil uptake}

Suspensions containing $10^{8} \mathrm{cells} / \mathrm{ml}$. of aerosolized and non-aerosolized bacteria were incubated in separate shake flasks with $0.025 \mu \mathrm{c} / \mathrm{ml}$. $\left({ }^{14} \mathrm{C}\right.$ )-uracil (The Radiochemical Centre, Amersham, Bucks) at $37^{\circ}$. The suspending fluid consisted of the glycerol medium described previously. Samples were taken at regular intervals. The ice-cold $5 \%(\mathrm{w} / \mathrm{v})$ trichloracetic acid soluble matter was filtered through a 'Millipore' filter. After washing the residue on the filter with cold water, the radioactivity in the combined filtrate and washings was determined at room temperature by a 'coincidence' scintillation counting technique (Anderson \& Smith, 1965). Reduction in the amount of radioactivity in the filtrate should correspond to the amount incorporated as ribonucleic acid. This was confirmed by extracting the ribonucleic acid from the residue on the filter with $5 \%$ trichloracetic acid at $60^{\circ}$ for $15 \mathrm{~min}$. After filtering, the radioactivity of the filtrate was measured at room temperature.

\section{Release into the medium of $\left({ }^{14} \mathrm{C}\right)$ from prelabelled $s-R N A$}

$\left({ }^{14} \mathrm{C}\right)$-labelled s-RNA was prepared by incubating a suspension of bacteria $\left(10^{11}\right.$ cells $\mathrm{ml}$.) in the glycerol growth medium with $\left({ }^{14} \mathrm{C}\right)$-uracil $\left(25 \mu \mathrm{c}\right.$. $/ \mathrm{ml}$.) at $37^{\circ}$ for $90 \mathrm{~min}$. The bacteria were collected and washed three times with distilled water before being sprayed. After storing the airborne bacteria in the drum apparatus for a certain time they were collected into the usual growth medium. This suspension was incubated at $37^{\circ}$ in a shake flask. A control suspension consisted of an identical quantity of $\left({ }^{14} \mathrm{C}\right)$-s-RNA unsprayed bacteria. Samples were taken at regular intervals. Each sample was treated with ice-cold $5 \%$ trichloracetic acid for $60 \mathrm{~min}$., filtered, and the residue was incubated at $60^{\circ}$ for $15 \mathrm{~min}$. and again filtered. The radioactivity of this filtrate was determined at room temperature. 
The synthesis of DNA

The effect of aerosolization on the synthesis of DNA in the bacteria was studied by measuring their uptake of $\left({ }^{14} \mathrm{C}\right)$-thymidine. The procedure involved is the same as for the uptake of $\left({ }^{14} \mathrm{C}\right)$-uracil.

\section{The release into the medium of $\left({ }^{14} \mathrm{C}\right)$ from prelabelled $D N A$}

The method of producing prelabelled $\left({ }^{14} \mathrm{C}\right)$-DNA bacteria and measuring the effect of aerosolization on the release of $\left({ }^{14} \mathrm{C}\right)$ as a result of DNA degradation was the same as described previously for s-RNA.

\section{The effect of air on the pyruvate metabolism of freeze-dried and aerosolized Escherichia coli $B$}

Washed bacterial suspension of Escherichia coli $\mathrm{B}$ was freeze-dried in glass ampoules. These samples were then exposed to: (i) air; (ii) nitrogen at controlled RH in vacuum desiccators. Control of the RH was effected by saturated solutions of certain inorganic salts (Wexler \& Hasegawa, 1955). After a certain exposure time the bacteria were resuspended in phosphate buffer.

Aerosolized bacteria were collected in phosphate buffer. Each suspension was made up of $5 \times 10^{8}$ bacterial $/ \mathrm{ml}$. in phosphate buffer, $10^{-3} \mathrm{M}-\mathrm{MgSO}_{4}$ and $1000 \mu \mathrm{M}$ sodium pyruvate, before incubation at $37^{\circ}$. Samples were taken at regular intervals and their pyruvate content was measured by the Friedmann \& Haugen method (1943).

The effect of air on the reduction of 2:4:6: triphenyl tetrazolium chloride by freeze-dried and aerosolized Escherichia coli $B$

A more concentrated suspension of bacteria was required to reduce the tetrazolium salt than was usually obtainable in the collecting fluid after aerosolization. Therefore the collected aerosolized bacteria were centrifuged and resuspended in one-fifth of the original volume of suspending fluid. The respective suspensions were made up of $5 \times 10^{8}$ bacteria $/ \mathrm{ml}$. in phosphate buffer, $5.0 \%(\mathrm{w} / \mathrm{v})$ glucose and $0.1 \%(\mathrm{w} / \mathrm{v})$ tetrazolium chloride (British Drug Houses Ltd.) before being incubated at $37^{\circ}$. The red insoluble formazan dye which developed was extracted from the cells by adding glacial acetic acid. The formozan was extracted from the aqueous phase by $n$-butanol and assayed spectrophotometrically at a wavelength of $540 \mathrm{~m} \mu$.

\section{RESULTS}

The percentage survivals of Escherichia coli B aerosolized at various $\mathrm{RH}$ values in air and in pure nitrogen and then collected after $10 \mathrm{~min}$. into phosphate buffer are given in Fig. 1. Survival in nitrogen was much greater than in air, progressively so as the RH level fell. At high RH the survival pattern was extremely sensitive to small RH changes: for example, between the RH values of $75 \%$ and $82 \%$, survival of $E$. coli B decreased from $36 \%$ to a minimum of $8 \%$. At very high $\mathrm{RH}$ values the survival curves of $E$. coli B stored in air or in nitrogen tend to merge. This result is very similar to that found by Cox (1966). Figure 2 shows that the death rate was initially very rapid, being dependent on the $\mathrm{RH}$, and was much faster in air than in 
nitrogen. The initial rapid death rate was followed by a much slower secondary one which in some cases approached zero and which was much less dependent on both $\mathrm{RH}$ and gaseous composition of the atmosphere.

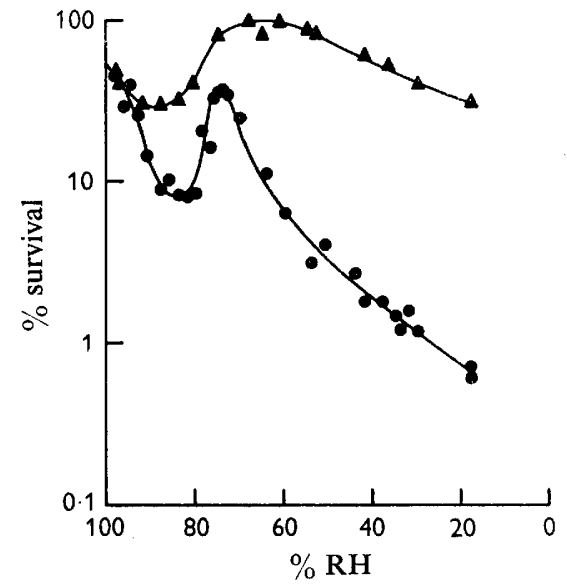

Fig. 1

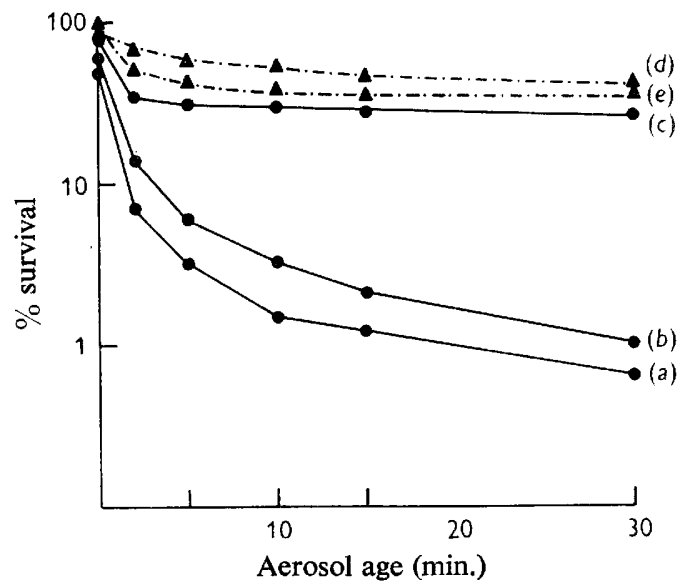

Fig. 2

Fig. 1. Survival of E. coli $\mathrm{B}$ at aerosol age of $10 \mathrm{~min} .--$, sprayed into air; - - sprayed into nitrogen.

Fig. 2. The death rate of aerosolized $E$. coli $\mathrm{B}$. - - , sprayed into air at $(a) 35 \% \mathrm{RH}$; (b) $50 \% \mathrm{RH}$; (c) $97 \% \mathrm{RH} . \cdot-\cdot-\mathbf{\Delta}_{-\cdot-\cdot}$, sprayed into nitrogen at $(d) 37 \% \mathrm{RH}$; (e) $95 \% \mathrm{RH}$.

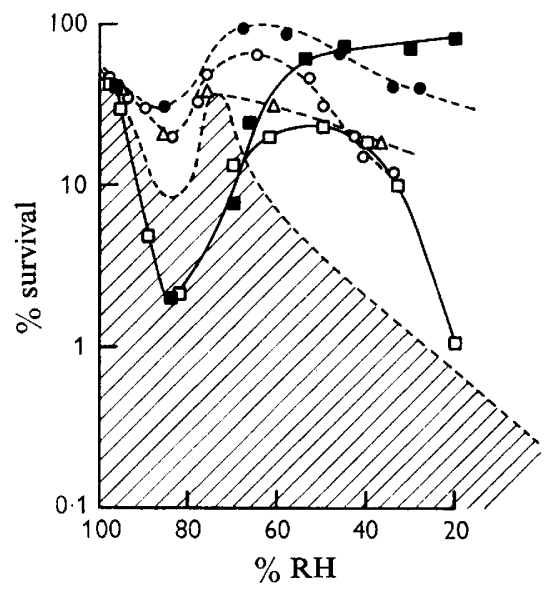

Fig. 3. Survival of $E$. coli в which have been incubated in the following chemicals: - - $O--$,

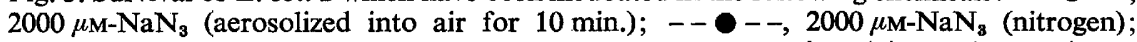
$-\square-, 10,000 \mu \mathrm{M}$-cysteamine (air); $-\square-, 10,000 \mu \mathrm{M}$-cysteamine (nitrogen); $--\triangle--$, $500 \mu \mathrm{M}-\mathrm{KNO}_{2}$ (air). The line above the shaded area shows the survival curve of $E$. coli $\mathrm{B}$ sprayed from distilled water into air.

\section{The deleterious effect of oxygen on bacterial survival}

In accordance with the findings of Hess (1965) and Cox (1966), oxygen was toxic to airborne bacteria. Furthermore, its toxicity progressively increased as the RH decreased below $70 \%$. Pre-incubation of Escherichia coli B with various inhibitors of 
the electron transport system such as sodium azide, potassium cyanide and 2,4-dinitrophenol, before spraying, was found to increase the aerosol stability of $E$. coli B considerably, particularly at low RH (Fig. 3).

The detection of altered metabolism which might contribute to the death of airborne bacteria has been hampered by the problem of collecting enough material from the aerosol. Chemicals such as potassium nitrite and cysteamine which have been shown to protect freeze-dried bacteria and irradiated bacteria against the lethal effect of oxygen (Lion \& Avi Dor, 1963; Baker, Ormerod, Dean \& Alexander, 1966) have



(a)

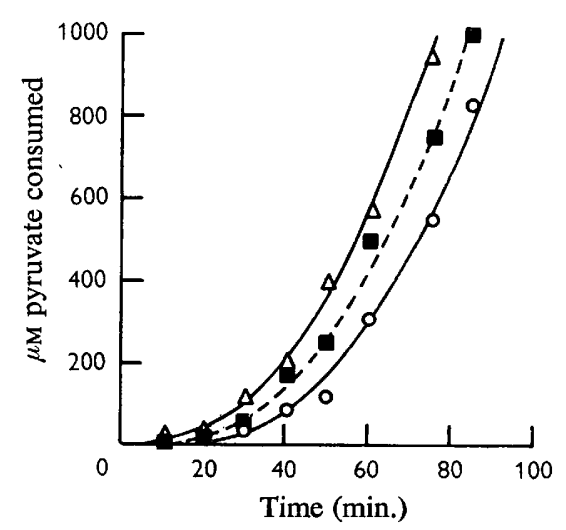

(b)

Fig. 4(a) The effect of air on the consumption of pyruvate by $E$. coli B which have been freeze-dried and exposed to air ( $-\square-$ ), or to nitrogen (-O-) for $4 \mathrm{hr}$ before being resuspended in phosphate buffer containing $1000 \mu \mathrm{M}$ sodium pyruvate and $10^{-3} \mathrm{M}-\mathrm{MgSO}_{4}$. This suspension contains $2 \times 10^{8}$ bacteria/ml.

Fig. $4(b)$ The effect of aerosolization on the ability of $E$. coli в to consume pyruvate. The bacteria were collected in phosphate buffer after being aerosolized into air ( $-\mathrm{O} \longrightarrow$ ) or into nitrogen $\left(--\square_{--}\right)$for $10 \mathrm{~min}$. Unsprayed cells are used as control $\longrightarrow \triangle \longrightarrow$.

also been found to give some degree of protection to airborne $E$. coli B at low RH. Lion \& Avi-Dor (1963), using a model enzyme system, were able to show that damage to a flavin-linked enzyme occurred on exposure of freeze-dried $E$. coli to oxygen. The effect of oxygen on the uptake of pyruvate by aerosolized and freeze-dried $E$. coli B (Fig. 4) may therefore be attributed to damaged flavin-linked enzymes connected with pyruvate metabolism (Benbough, 1965). Also, both aerosolization and exposure of freeze-dried $E$. coli в to air caused a great diminution in the reduction of tetrazolium chloride to formozan compared to results obtained by exposure to nitrogen.

\section{Synthesis and breakdown of nucleic acids after aerosolization of Echerichia coli $B$}

Data given on Fig. 5 indicate that the effect of aerosolization on the kinetics of the ability of Escherichia coli $\mathrm{B}$ to synthesize RNA was dependent on RH but was independent of the carrier gas. The RNA synthesizing ability of $E$. coli B decreases after being aerosolized into higher RH values. This diminution in the rate of RNA 
synthesis appears to enhance the chances of the bacteria surviving in the aerosol and it may be attributable to mechanisms that degrade or release RNA from the bacteria. Loss of cellular RNA occurred to a maximal extent in bacteria which were aerosolized at $70 \%$ RH (Fig. 6) which coincides with the RH where maximal survival occurs. Unequivocal evidence that differences in the rate of RNA breakdown in $E$. coli B aerosolized at various RH values may be attributed to fluctuations in the



Fig. 5

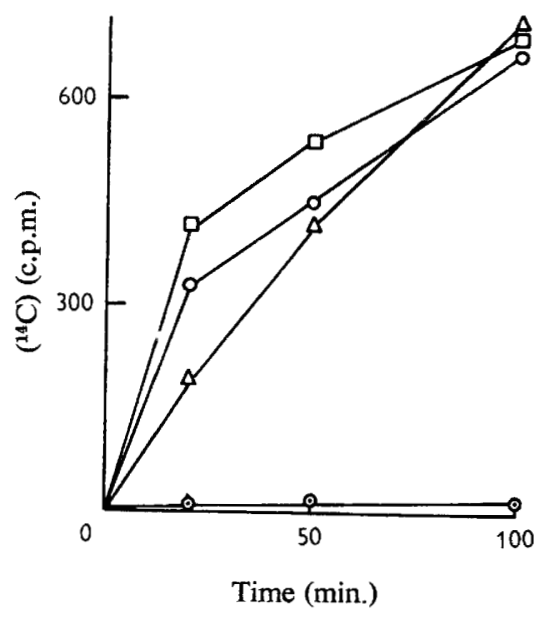

Fig. 6

Fig. 5. The effect of aerosolization on the uptake of $\left({ }^{14} \mathrm{C}\right)$-uracil by $E$. coli B $\left(10^{8} \mathrm{cells} / \mathrm{ml}\right.$.). - Control unsprayed bacteria. The following represent bacteria aerosolized for 10 min.: $-\Delta-$, at $35 \% \mathrm{RH}$ in air; $-\Delta-$, at $35 \% \mathrm{RH}$ in nitrogen; - - , at $72 \% \mathrm{RH}$ in air; - $\square-$, at $82 \% \mathrm{RH}$ in air; - - , at $98 \% \mathrm{RH}$ in air; $-\times-$, at $98 \% \mathrm{RH}$ in nitrogen.

Fig. 6. The effect of aerosolization of $E$. coli $\mathrm{B}$ on the breakdown of $\left({ }^{14} \mathrm{C}\right)$-s-RNA into a cold acid-soluble fraction. - $\odot-$, control unsprayed $E$. coli в $\left(10^{8}\right.$ cells $/ \mathrm{ml}$.). The following represent results of bacteria aerosolized for $10 \mathrm{~min}$, in air: $-\triangle-$, at $\mathrm{RH} 95 \%$; $-\square-$, at RH $66 \%$; - $\mathrm{O}-$, at $\mathrm{RH} 35 \%$.

RNAse activity was extremely difficult to obtain. However, Webb (1965) has shown that the RNAse activity of $E$. coli dried at $80 \% \mathrm{RH}$ is nearly double those dried at $30 \% \mathrm{RH}$. Support for the view that RNAse activity may contribute to aerosol stability may be obtained from the fact that: (i) $\mathrm{Mg}^{2+}$-starved $E$. coli $\mathrm{B}$, which have an enhanced RNAse activity (H. E. Wade, personal communication) have greater, aerosol stability than $E$. coli B grown in normal chemically defined medium (Fig. 7); (ii) E. coli strain 600 M.R.E. which has exceptionally small RNAse activity (Wade \& Robinson, 1966) has a very low aerosol stability.

No apparent differences in the kinetics of DNA synthesis and breakdown in aerosolized Escherichia coli could be detected by the techniques in this paper (Fig. 8).

\section{DISCUSSION}

The kinetics of death rate show that oxygen and certain factors associated with the rate of dehydration contribute to the instantaneous death of airborne Escherichia coli B. The rapidity of death makes it virtually impossible to assess quantitatively 
the interdependence of these lethal factors but this study indicates that the toxicity of oxygen increases in relation to the dryness of the air. At high RH values mechanisms lethal to airborne $E$. coli B must be independent of the presence of oxygen. The kinetics of death of $E$. coli $\mathrm{B}$ in air and nitrogen at high RH values were similar, indicating that other mechanisms contribute to their death, which is independent of the presence of oxygen (Fig. 2).



Fig. 7

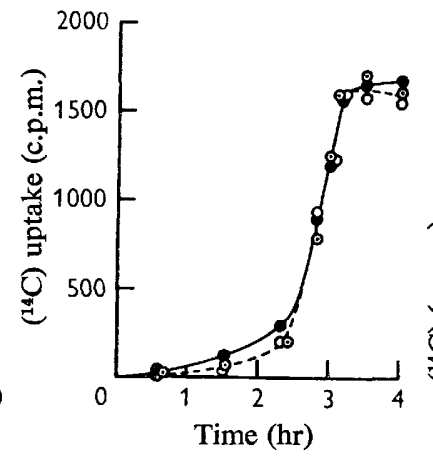

Fig. $8(a)$

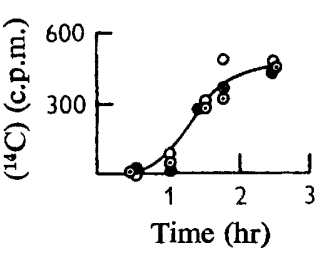

Fig. 8 (b)

Fig. 7. Survival of magnesium-starved E. coli в aerosol age of $10 \mathrm{~min}$. in air. Interrupted curve, survival after growth in normal medium (from Fig. 1).

Fig. 8(a). The effect of aerosolization on the uptake of $\left({ }^{14} \mathrm{C}\right)$ thymidine by $E$. coli $\mathrm{B}$ $\left(10^{8} \mathrm{cells} / \mathrm{ml}\right.$.). - - c control unsprayed bacteria. - - - , bacteria aerosolized at $35 \% \mathrm{RH}$ in air for $10 \mathrm{~min} . ;-\odot-$, bacteria aerosolized at $98 \% \mathrm{RH}$ in air for $10 \mathrm{~min}$.

Fig. 8(b). The effect of aerosolization of $E$. coli $\mathrm{B}$ on the breakdown of $\left({ }^{14} \mathrm{C}\right)$-DNA into a cold acid-soluble fraction. $\bullet$, control unsprayed $E$. coli $\left(10^{8} \mathrm{cells} / \mathrm{ml}\right.$.). The following represent results of E. coli aerosolized for $10 \mathrm{~min}$. in air: O, at $35 \%$ R.H.; $\odot$ at $98 \%$ RH.

Indications that exposure of freeze-dried Escherichia coli в to oxygen-induced effects on the flavin-linked pyruvate oxidation similar to airborne $E$. coli $\mathrm{B}$ enable one mechanism of death of airborne $E$. coli $\mathrm{B}$ to be suggested. Contact between oxygen and freezedried $E$. coli results in the death of the bacteria and the formation of detectable free radicals (Lion, Kirby-Smith \& Randolph, 1961; Dimmick, Heckley \& Hollis, 1961). Most cellular oxidations are mediated by the pyridine nucleotide-flavoprotein-cytochrome $c$-cytochrome oxidase system, and recently Fox \& Tollin (1966) have shown that the mechanism of flavoenzyme action involves radical formation. Consequently, the function of flavin radicals as mediators may well be interfered with as a result of (i) radical propagation; (ii) radical abstraction; (iii) radical combination with foreign radicals formed by the action of oxygen on freeze-dried or airborne $E$. coli $\mathrm{B}$; or (iv) oxygen may combine directly with the flavin radicals to form lethal peroxide radicals. Decreasing the metabolism of bacteria is known to protect them against the lethal effect of oxygen (Goodlow \& Leonard, 1961; Gerschman et al. 1954). Also, preincubation of the bacteria in metabolic inhibitors such as sodium azide, potassium cyanide and 2,4-dinitrophenol protects the bacteria to some degree. This must be associated with a decrease in the rate of flavin radicals formed, thus limiting the above lethal effects on airborne bacteria. Confirmation that the electron transport system of airborne $E$. coli B was damaged by oxygen was produced by the fact that bacteria which were aerosolized into air failed to reduce triphenyl tetrazolium chloride. 
A free-radical scavenger, cysteamine, when pre-incubated prior to spraying, increases the viability of Escherichia coli B considerably at low RH values. The mechanism by which cysteamine protects is unknown but it may be related to its protective action against the effect of oxygen on irradiated $E$. coli (Baker et al. 1966).

At high RH values the extent of death of Escherichia coli в in air and in nitrogen were similar, indicating that other mechanisms independent of the presence of oxygen contribute to death. Cox \& Baldwin (1966) demonstrated that the mechanism of death at high RH was different to that caused by oxygen. The considerable effect which aerosolization had on the s-RNA synthesis in $E$. coli B was found to be independent of the carrier gas used but changed considerably with changes in RH. Generally, as the $\mathrm{RH}$ increased, the initial rate by which aerosolized $E$. coli B can synthesize s-RNA gradually decreased. At low RH values (below $40 \%$ ) the initial synthesis of s-RNA suddenly ceases and a rapid breakdown of s-RNA takes place. At high RH values (above $85 \%$ ) an enhanced lag period occurred before s-RNA synthesis commenced. The sensitivity of airborne $E$. coli в to RH may be due to the great dependence upon $\mathrm{RH}$ of the effect of aerosolization on s-RNA synthesis. No adequate explanation can be afforded for the pronounced minimal survival of aerosolized $E$. coli $\mathrm{B}$ at the RH of $83 \%$, also found by Cox (1966).

Evidence in this report supports the view that ribonuclease activity may increase

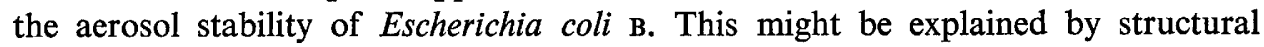
modifications in the nucleic acids during aerosolization of the bacteria. These modifications, which might lead to some lethal biosynthesis of proteins, could thus be prevented by the destructive action of RNAse on the s-RNA.

The author thanks Mr I. H. Silver and Dr C. S. Cox for their interest and much helpful discussion and thanks Miss J. Soilleux for technical assistance.

\section{REFERENCES}

Anderson, J. D. \& SMITh, H. (1965). The metabolism of erythritol by Brucella abortus. J. gen. Microbiol. 38, 109.

BaKer, A., OrMEROD, M. G., DeAN, C. \& AleXANDer, P. (1966). The reaction of radicals induced in Escherichia coli $\mathrm{B} / \mathrm{r}$ by X-rays with cysteamine and with oxygen. Biochim. biophys. Acta 114, 169.

Bateman, J. B., MCCAFfrey, P. A., O'ConNoR, R. J. \& MonK, G. W. (1961). Relative humidity and killing of bacteria: the survival of damp Serratia marcescens in air. Appl. Microbiol. 9, 567.

BenBOUGH, J. E. (1965). The chemical basis of the bacteriostatic actions of some tetracyclines. Ph.D. thesis, University of Wales.

Cox, C. S. (1966). The survival of Escherichia coli sprayed into air and into nitrogen from distilled water and from solution of protecting agents as a function of relative humidity. J. gen. Microbiol. 43, 387.

Cox, C. S. \& Baldwin, F. (1966). The use of phage to study causes of loss of viability of Escherichia coli in aerosols. J. gen. Microbiol. 44, 15.

Davis, M. S. \& Bateman, J. B. (1960). Relative humidity and the killing of bacteria. 1. Observations on Escherichia coli and Micrococcus lysodeikticus. J. Bact. 80, 577.

Dimmick, R. L., HeCKLey, R. S. \& Hollis, D. P. (1961). Free-radical formation during storage of freeze-dried Serratia marcescens. Nature, Lond. 192, 776.

Dunkirn, E. W. \& PUCK, T. T. (1948). The lethal effects of relative humidity on airborne bacteria. J. exp. Med. $87,87$.

Fox, J. L. \& Tollin, G. (1966). A flavoenzyme model system. Abstracts of the Biophysical Society, 10 th Annual Meeting.

Friedmann, T. E. \& Haugen, G. (1943). The determination of keto acids in blood and urine. J. biol. Chem. 147, 415. 
Gerschman, R., Gilbert, D. L., Nye, S. W., Dwyer, P. \& FenN, W. O. (1954). Oxygen poisoning and X-irradiation: A mechanism in common. Science 119, 623.

Goodlow, R. J. \& LeONARD, F. A. (1961). Viability and infectivity of micro-organisms in experimental airborne infection. Bact. Rev. 25, 182.

Hess, G. E. (1965). Effects of oxygen on aerosolized Serratia marcescens. Appl. Microbiol. 13, 781.

LION, M. B. \& Avi-Dor, Y. (1963). Oxygen induced inactivation of NADH oxidase in lyophilized cells of Escherichia coli. Israel J, chem. 1, 374.

Lion, M. B., KirbY-Smith, J. S. \& RANDOLPH, M. L. (1961). Electron spin resonance signals from lyophilized cells exposed to oxygen. Nature, Lond. 192, 34.

WADE, H. E. \& Robinson, H. K. (1966). Magnesium-independent ribonucleic acid depolymerases in bacteria. Biochem. J. 101, 467.

WeBB, S. J. (1965). Bound Water in Biological Integrity, p. 157, Springfield, Illinois, U.S.A.: C. C. Thomas.

WeXiER, A. \& HASEgawa, S. (1955). Relative humidity-temperature relationships of some saturated salt solutions in the temperature range $0-50^{\circ} \mathrm{C}$. J. Res. (Nat. British Standards), 53, 19. 